\title{
Hormonal contraceptive use in Norway, 2006-2020, by contraceptive type, age and county: A nationwide register-based study
}

\author{
Kari Furu ${ }^{1,2}$, Ellen Barth Aares ${ }^{3}$, Vidar Hjellvik ${ }^{1}$ and Øystein Karlstad ${ }^{1}$ \\ 1) Department of Chronic diseases and Ageing, Norwegian Institute of Public Health, Oslo, Norway \\ 2) Centre for Fertility and Health, Norwegian Institute of Public Health, Oslo, Norway \\ 3) Norwegian Medicines Agency, Oslo, Norway \\ E-mail: kari.furu@fhi.no. Telephone:+4795221824
}

\begin{abstract}
Aim: Our aim was to study hormonal contraceptive use among women in Norway during 2006-2020 according to age groups and geography, including choice of contraceptive method, type of prescriber for long-acting reversible contraceptives, and prescriber's adherence to the national health authority recommendations.

Material and methods: We conducted a nationwide drug utilization study including all women aged 16-49 years in Norway during 2006-2020. The Norwegian Prescription Database (NorPD) includes detailed information about all dispensed prescription medications from Norwegian pharmacies to individuals in ambulatory care, including year of dispensing, patient's year of birth and county of residence, and the prescriber's profession.

Results: This study shows a slight increase in overall use of hormonal contraceptives among 16-49-year-olds during 2006-2018, increasing from $36 \%$ of the population to $40 \%$. Combined oral contraceptives (COCs) was the most commonly used hormonal contraceptive method in all age groups. The use of COCs decreased during the period and the decline was greatest in those below 25 years. From $201680 \%$ of all new users of COCs received the recommended COC containing levonorgestrel. Use of estrogen-free contraceptives, long-acting reversible contraceptives (LARCs) and gestagen pills, has increased. After 2014 the use of LARCs, especially subdermal implant, increased steeply among younger women. Oslo had the lowest proportion of users of hormonal contraceptives among teenagers and young adults during the whole period, while among 30-49-yearolds Oslo was more in line with the other counties.

Conclusion: Combined oral contraceptives (COC) was the most used hormonal contraceptive method in all age groups. However, the use of COCs decreased during the period, especially in those $<25$ years, where a corresponding increase in the use of LARC has taken place, mainly from 2014 onwards. Four out of five women who initiated COC received the recommended COC type and the steep increase in use of estrogen-free LARCs in recent years implies that Norwegian prescribers have high compliance with the recommendations from the health authorities.
\end{abstract}

This is an open access article distributed under the Creative Commons Attribution Licence, which permits unrestricted use, distribution, and reproduction in any medium, provided the original work is properly cited.

\section{BACKGROUND}

The first combined oral contraceptives containing both progestagen and estrogen were launched in the 1960s. Since then, the estrogen component has decreased due to association with the risk of venous thromboembolism. Later on the progestagen component has received more attention as some studies reported different risks of venous thromboembolism (VTE) by type of gestagen $(1,2)$. In 2009, the Norwegian Medicines Agency (NoMA) recommended that new users of combined oral contraceptives should be prescribed those containing the progestagen levonorgestrel (called "secondgeneration contraceptives"). In 2010, NoMA launched a campaign in collaboration with the Norwegian Directorate of Health to make the change in national recommendations known (3). Later, in November 2013, the European Medicines Agency (EMA) completed its review of combined hormonal contraceptives, particularly of the risk of VTE associated with their use (4). The conclusion was that women using secondgeneration contraceptives (containing levonorgestrel) had a lower risk of VTE than those who use third (e.g. Marvelon ${ }^{\circledR}$ containing desogestrel) or fourth generation contraceptives (e.g. Yasmin ${ }^{\circledR}$ containing drospirene). The review led to an update of the product information for each of the individual COCs and a decision by NoMA to send out a letter to healthcare professionals. Subsequently, all prescribers in Norway received a letter with updated information in January 2014 (5). To reduce the risk of VTE NoMA recommends that women who begin with hormonal contraception choose one of these options: long-acting reversible contraceptive (LARC), gestagen pill, or combined oral contraceptive (COC) with estrogen and levonorgestrel.

To prevent unwanted pregnancies and abortions among teenagers the Norwegian Ministry of Health introduced a reimbursement scheme with free contraceptive pills for girls aged 16 to 19 from 1 January 2002. In addition, public health nurses and midwives in public school health services were permitted to prescribe oral contraceptives to girls in the same age group from 1 June 2002 $(6,7)$. This arrangement has been changed several times (Info Box 1) and as of 2016 public health nurses have 
Info Box 1. An overview of changes in reimbursement scheme for hormonal contraceptives and changes in public health nurses' and midwives' rights to prescribe contraceptives in Norway during 2002-2020.

\begin{tabular}{|c|c|c|}
\hline & Reimbursement scheme & Prescribing regulations \\
\hline 2002 & $\begin{array}{l}\text { January: Free of charge for selected contraceptive pills (Trionetta }{ }^{\circledR} \text {, } \\
\text { Trinordiol } \AA \text {, Follimin } \AA \text {, Loette } \AA \text { and Microgynon } \AA \text { ) for women aged } 16 \\
\text { to } 19 \text { years }\end{array}$ & $\begin{array}{l}\text { June: Public health nurses and midwives } \\
\text { were given the right to prescribe } \\
\text { selected contraceptive pills (Trionetta }{ }^{\circledR} \text {, } \\
\text { Trinordiol }(\text {, Follimin } ₫ \text {, Loette } ₫ \text { and } \\
\text { Microgynon }{ }^{\circledR} \text { ) for women aged } 16 \text { to } 19 \\
\text { years }\end{array}$ \\
\hline 2006 & $\begin{array}{l}\text { March 2006: a fixed reimbursement rate introduced for hormonal } \\
\text { contraceptives for women aged 16-19*. The reimbursement was set to } \\
\text { cover up to NOK } 100 \text { for } 3 \text { months of use. This reimbursement scheme } \\
\text { was to replace the scheme with free contraceptive pills and be extended } \\
\text { to include more contraceptive preparations such as contraceptive patches, } \\
\text { contraceptive ring and contraceptive injection (the scheme covers the } \\
\text { gestagen pill Cerazette } \circledast \text { and all preparations except for subdermal } \\
\text { contraceptive implant (p-stav) and hormonal intrauterine device (spiral) }\end{array}$ & $\begin{array}{l}\text { Public health nurses and midwives' } \\
\text { rights to prescribe were extended to } \\
\text { cover several contraceptive } \\
\text { preparations, including contraceptive } \\
\text { rings and contraceptive patches }\end{array}$ \\
\hline 2015 & $\begin{array}{l}\text { The subdermal contraceptive implant and hormonal intrauterine device } \\
\text { were included in the reimbursement scheme }\end{array}$ & \\
\hline 2016 & & $\begin{array}{l}\text { Public health nurses and midwives were } \\
\text { given the right to prescribe all hormonal } \\
\text { contraceptives including long-acting, } \\
\text { reversible contraceptives (LARC) for } \\
\text { women } 16 \text { years and older }\end{array}$ \\
\hline 2018 & $\begin{array}{l}\text { The reimbursement scheme to include all contraceptives in the ATC } \\
\text { groups G02B, G03AA, G03AB, G03AC and copper IUD. The scheme } \\
\text { has been extended to apply to women from } 16 \text { to } 20 \text { years of age* }\end{array}$ & \\
\hline 2019 & $\begin{array}{l}\text { The scheme has been extended to apply to women from } 16 \text { to } 21 \text { years of } \\
\text { age* (the scheme applies from the month after the woman turns } 16 \text { up to } \\
\text { and including the month before the woman turns } 22 \text { ) }\end{array}$ & \\
\hline
\end{tabular}

* Some contraceptives will be completely free while others (some LARC) will have a co-payment (egenandel), for this age group. Per 2019: Young women between the ages of 16 and 22 receive contraceptives free of charge or have part of the costs covered. Women who are 16,17 , 18 or 19 years old receive an intrauterine device and a subdermal implant free of charge. Women who are 20 or 21 years, do not get the full cost covered and must pay a deductible (egenandel).

had the right to prescribe all contraceptives including LARCs to women 16 years and older $(8,9)$.

Our aim was to study hormonal contraceptive use among women in Norway during 2006-2020 according to age groups and geography, including choice of contraceptive method, type of prescriber for long-acting reversible contraceptives, and prescriber's adherence to the national health authority recommendations.

\section{MATERIAL AND METHOD}

The nationwide Norwegian Prescription Database (NorPD) includes detailed information about all prescription medications dispensed from Norwegian pharmacies to individuals in ambulatory care (10), including year of dispensing, patient's year of birth and county of residence, and prescriber's profession. All medications in NorPD are classified according to the Anatomical Therapeutic Chemical classification (ATC) system (11). There are several types of hormonal contraceptives on the market in Norway: some contraceptives containing both progestagen and estrogen (COCs, vaginal rings, patches), and some containing only progestagen (gestagen pills and different long-acting reversible contraceptives (LARCs)). We grouped the hormonal contraceptives into four groups (Table 1). All women aged 16-49 years during 2006-2020 were included.

We computed three-year prevalence of LARCs (group 3 ) and one-year prevalence of the other groups of contraceptives. The three-year prevalence of LARCs in 2006 for age group 16-49 was computed as the number of women born in the period 1957 through 1990 who were dispensed at least one LARC in 2006, 2005, or 2004 , divided by the population of 16-49-year-old women per 1.1.2006 from Statistics Norway. Correspondingly, for other years, groups of contraceptives and age groups. The three-year prevalence for LARCs prescribed by doctors was computed the same way but ignoring all prescriptions where the prescriber was not a doctor (ForskriverProfesjonKode $=$ LE). Similarly, for nurses/midwives (ForskriverProfesjonKode $=\mathrm{SP}$ or $\mathrm{JO})$.

The numerator for the prevalence of any contraceptives combined in 2006 was the number of women who received a LARC in 2004-2006 or a contraceptive in group 1, 2, or 4 in 2006. We had access to individual level data for 2004-2018 (Ethical approval: 2017/2546/ REK sør-øst) but had used tabulated data from a web- 
Table 1. Subdivision of different hormonal contraceptives into 4 groups.

\begin{tabular}{lllll}
\hline Group & Contraception type & ATC codes & Hormone content & Norwegian designation \\
\hline 1 & Combined oral contra- & G03AA06, G03AA07, & Estrogen \& progestagen & Kombinasjons p-piller \\
& ceptive pills (COC) & G03AA09, G03AA12, & & \\
& & G03AA14, G03AB03, & & \\
\hline 2 & G03AB04, G03AB08 & & Gestagenpiller/minipiller \\
& Gestagen pills & G03AC01, G03AC02, & Progestagen & \\
\hline 3 & Long-acting reversible & G03AC03, G03AC09 & & p-stav \\
& contraceptives (LARC) & contraceptive implant; & & livmorinnlegg/hormonspiral \\
& & G02BA03 Intrauterine & & \\
\hline 4 & Other contraceptives & G02BB01 Vaginal ring; & Estrogen \& progestagen & Vaginal ring \\
& & G03AA13 p-patch; & Estrogen \& progestagen & p-plaster \\
& & G03AC06 p-injectable; & Progestagen & p-sprøyte \\
& & G03HB01 antiandrogen & Estrogen \& antiandrogen & p-pille med antiandrogen \\
\hline
\end{tabular}

based application (similar to the public webpage http://norpd.no/Prevalens.aspx, but a bit more detailed) for 2019-2020. The combined one- and three-year prevalence was not possible to obtain from this application, and thus the combined prevalence is lacking for 2019 and 2020.

For prevalence per county, the 2020 definition of counties was used. Patients who were dispensed medications as residents of two (or more) counties the same year were counted as users in both (all) counties. For three-year prevalence in e.g. 2009, patients who lived in county X in 2007 or 2008 were counted as users in county $X$ in 2009 independent of where they lived in 2009 (we did not have access to individual domestic relocation history).

Among women who started with a COC as their first ever hormonal contraceptive, we computed the proportion who started with a recommended levonorgestrelcontaining COC (ATC code G03AA07 or G03AB03) by year and age.

\section{RESULTS}

The use of hormonal contraceptives was assessed in 2.3 million women in Norway aged 16-49 years. There was a slight increase in overall use of hormonal contraceptives among 16-49-year-olds during 2006-2018, ranging from $36 \%$ to $40 \%$. Among 16-19-year-old women, the prevalence of overall use varied from 53\% in 2012-2014 up to $57 \%$ in 2018 . The proportion of users was highest among 20-24-year-old women, increasing from $63 \%$ in 2006 to $69 \%$ in 2018 (figure 1).

Combined oral contraceptives (COC) was the most frequently used method in all age groups. However, the use of COCs decreased during the period and the decline was greatest in those below 25 years: from $49 \%$ in 2006 to $30 \%$ in 2020 in 16-19-year-old and from 48\% to $38 \%$ in $20-24$-year-old women. The use of LARCs was quite stable until 2014. After 2014 the use of LARCs increased especially among younger women: from $5.7 \%$ in 2015 to $25 \%$ in 2020 for $16-19$-year-old and from $7.8 \%$ to $26 \%$ for 20 -24-year-old women. Use of progestagen pills increased gradually, but more for the youngest age-groups: from $3.4 \%$ in 2006 to $11 \%$ in 2020 for $16-19$-year-olds and from $6.4 \%$ to $12 \%$ for 20 24-year-old women. Use of other contraceptives, e.g. ppatches and vaginal rings, has decreased throughout the period.

Among women who started with $\mathrm{COC}$ as their first ever hormonal contraceptive between 2007 and 2010, $40 \%$ of users were prescribed the recommended levonorgestrel-containing COC. From 2011 the proportion of COC-starters who filled a prescription of the recommended COC increased, and after 2016 the proportion was over $80 \%$ (table 2 ). The highest proportion of new users of the recommended COC was among 17 18-year-old girls in 2017-2018; about 87-89\%.

Table 2. Number $(\mathrm{N})$ of new users of combined oral contraceptives (COC) in the period 2006-2018, and the proportion (\%) of these that filled a prescription of a levonorgestrel-containing COC (ATC code G03AA07 or G03AB03). New use is defined as having no COC prescription in NorPD before the year of interest, but prescriptions for other hormonal contraceptives are allowed.

\begin{tabular}{lcc}
\hline & \multicolumn{2}{c}{ 16-49 years } \\
\cline { 2 - 3 } Year of \\
dispensing & $\begin{array}{c}\text { Number (N) of new } \\
\text { users of COC }\end{array}$ & $\begin{array}{c}\text { Proportion (\%) prescribed } \\
\text { a levonorgestrel- } \\
\text { containing COC }\end{array}$ \\
\hline 2006 & 47085 & 58.8 \\
2007 & 41604 & 38.0 \\
2008 & 37928 & 41.6 \\
2009 & 34957 & 36.4 \\
2010 & 34656 & 38.0 \\
2011 & 33311 & 44.4 \\
2012 & 32437 & 63.5 \\
2013 & 32823 & 68.7 \\
2014 & 32021 & 76.0 \\
2015 & 30292 & 78.1 \\
2016 & 28647 & 80.1 \\
2017 & 26748 & 81.6 \\
2018 & 24826 & 80.7 \\
\hline
\end{tabular}


Age 16-49

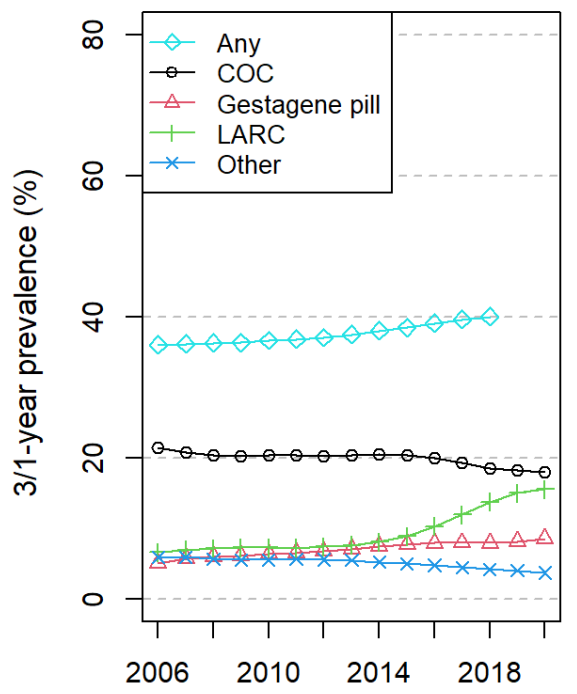

Age 16-19

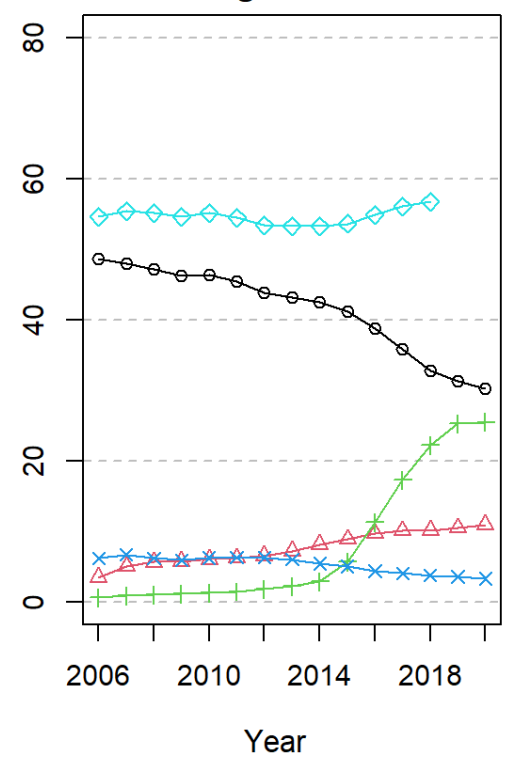

Age 20-24

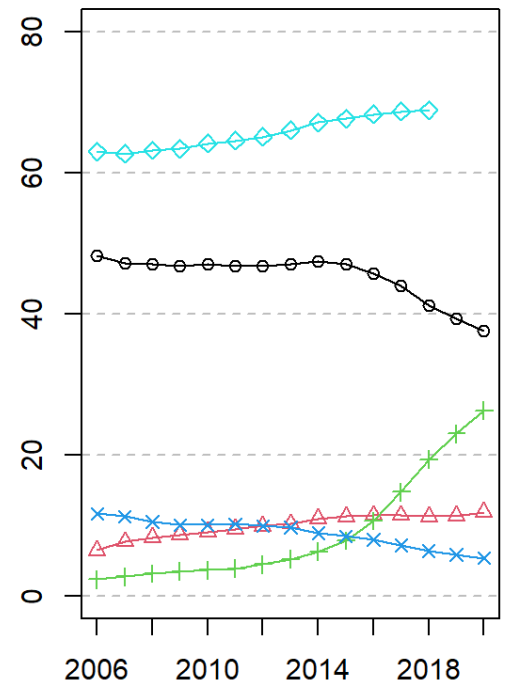

Figure 1. Prevalence (\%) of women in different age-groups who filled prescriptions of various types of hormonal contraceptives in the period 2006-2020. Three-year prevalence for LARC, one-year prevalence for the other groups. Labels: $\mathrm{COC}=\mathrm{Combined}$ oral contraceptives with estrogen and progestagen; LARC $=$ Long-acting reversible contraceptives (Subdermal implant \& Intrauterine device with progestagen); Other: vaginal ring, p-patch, p-injectable, COC with estrogen and antiandrogen.
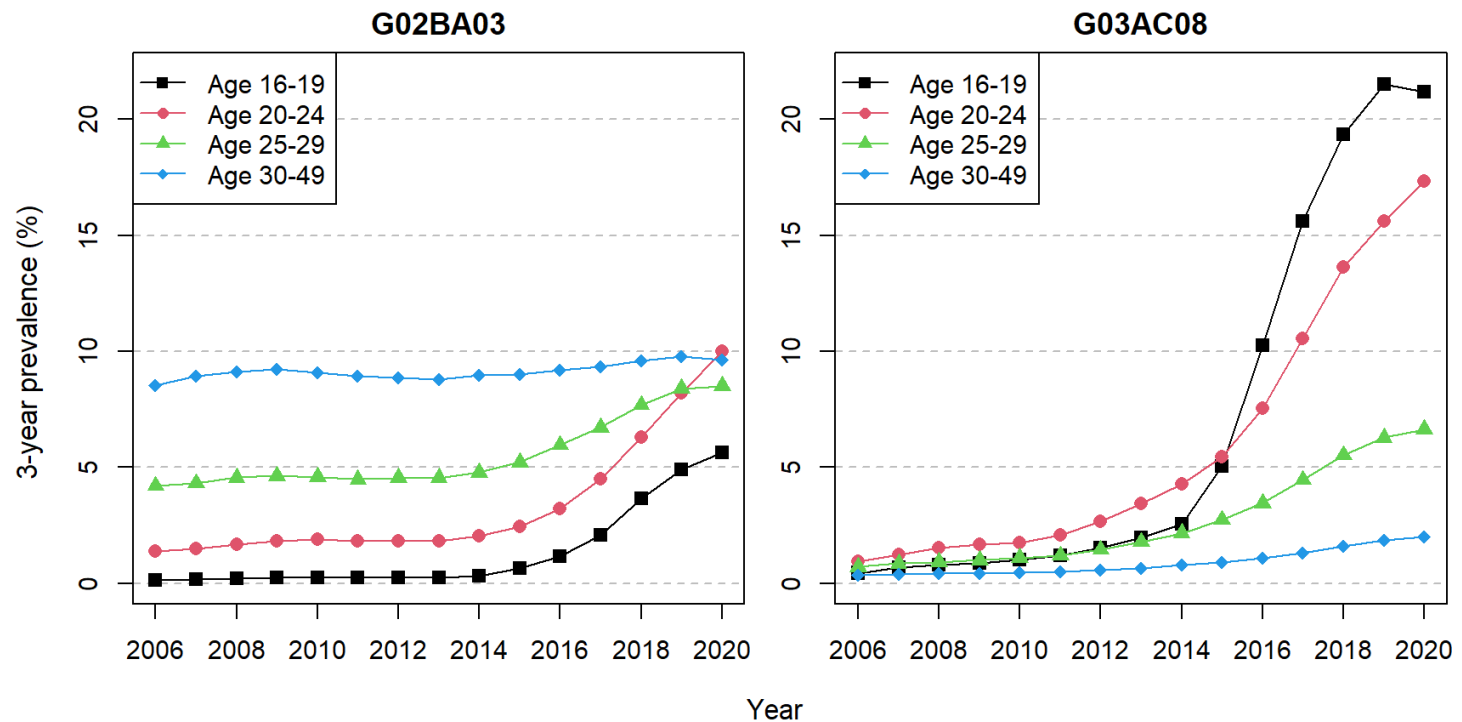

Figure 2. Three-year prevalence (\%) of women who have filled prescriptions for Long-acting reversible contraceptives (LARC): intrauterine device with progestagen (ATC code G02BA03) or implant (ATC code G03AC08) by age group in the period 2006-2020.

The use of LARCs was quite stable among women over 30 years but increased in teenagers and young adults during the observational period (figure 2). Use of implant increased steeply from $5.1 \%$ in 2015 to $21.2 \%$ in 2020 for women aged 16-19 years and similarly from $5.5 \%$ to $17.3 \%$ for women aged $20-24$ years. Use of intrauterine devices (IUDs) was lowest among teenagers and highest among those $>30$ years. However, after 2015 the increase in use of IUDs was greatest in the youngest: from $0.7 \%$ in 2015 to $5.6 \%$ in 2020 for $16-19$ years and from $2.4 \%$ to $10.0 \%$ for women aged $20-24$ years.
In 2015, 3.3\% of new users of LARCs among 16-19year-old girls were prescribed LARC by a public health nurse, increasing to $58.3 \%$ in 2020 . Similarly, for 20 24-year-old women $0.4 \%$ got their first prescription of LARC from a public health nurse in 2015 , increasing to $21.8 \%$ in 2020 (Table 3).

Oslo had the lowest proportion of users of hormonal contraceptives among teenagers and young adults during the whole period, while among those $30-49$ years, Oslo was more in line with the other counties (figure 3). Innlandet county had the highest proportion of users in those below 30 years. Among women 30-49-year-old, 


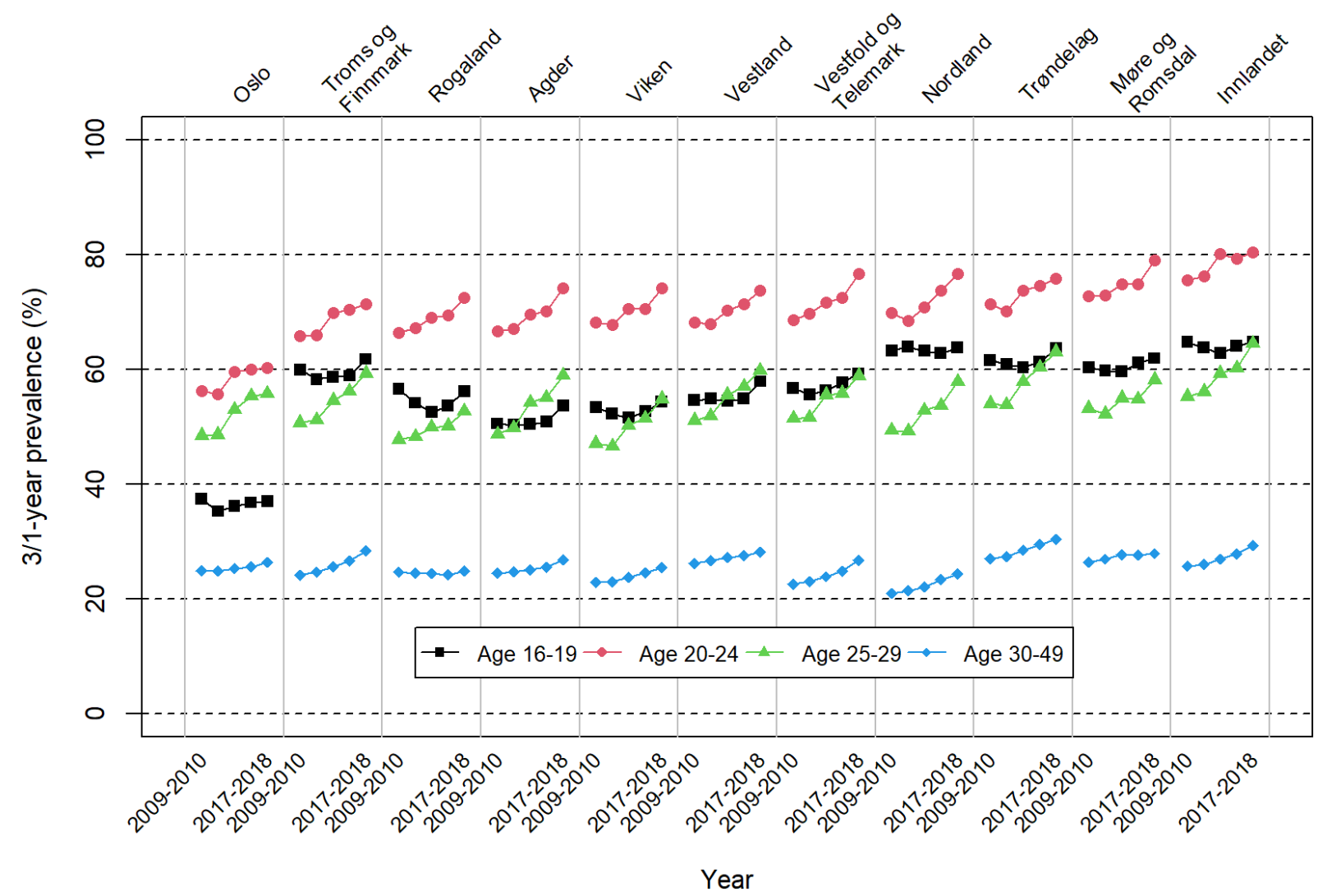

Figure 3. Prevalence (\%) of use* of any hormonal contraceptive in women by county and age group in the period $2009-2018$. Two-year averages and sorted by increasing prevalence in the 20-24 age group. *A filled prescription for LARC at least once the actual year or the two years before ("three-year prevalence"), or a filled prescription for other contraceptives the actual year.

Table 3. Number (N) of new users of LARC in the period 2013- 2018, and the proportion (\%) of these that filled their first prescription of LARC from a public health nurse or a midwife. New use is defined as having no LARC prescription in NorPD before the actual year, but prescriptions of other hormonal contraceptives are allowed.

\begin{tabular}{lcccc}
\hline & \multicolumn{2}{c}{$16-19$ years } & \multicolumn{2}{c}{$20-24$ years } \\
\cline { 2 - 5 } Year of & $\begin{array}{c}\text { Number of } \\
\text { new users of } \\
\text { dispensing }\end{array}$ & $\begin{array}{c}\text { Proportion } \\
\text { prescribed by } \\
\text { LArse/midwife (\%) }\end{array}$ & $\begin{array}{c}\text { Number of } \\
\text { new users of } \\
\text { LARC (N) }\end{array}$ & $\begin{array}{c}\text { Proportion } \\
\text { prescribed by } \\
\text { nurse/midwife (\%) }\end{array}$ \\
\hline 2013 & 1445 & 1.2 & 3131 & 0.2 \\
2014 & 1889 & 1.5 & 3754 & 0.1 \\
2015 & 5061 & 3.3 & 4831 & 0.4 \\
2016 & 9223 & 45.1 & 6736 & 14.4 \\
2017 & 11295 & 53.1 & 7881 & 17.6 \\
2018 & 12658 & 58.3 & 8609 & 21.8 \\
\hline
\end{tabular}

the proportion of users in 2017-2018 varied from $24 \%$ in Nordland county to $30 \%$ in Trøndelag county. Among women 16-19 years, the proportion of users in 20172018 varied from $37 \%$ in Oslo to $65 \%$ in Innlandet. Among women 20-24 years, the proportion of users in 2017-2018 varied from $60 \%$ in Oslo to $80 \%$ in Innlandet.

\section{DISCUSSION}

This nationwide study shows a slight increase in overall use of hormonal contraceptives among 16-49-year-olds during $2006-2018$, from $36 \%$ to $40 \%$. The proportion of users was highest among 20-24-year-old women (69\% in 2018). Combined oral contraceptives (COC) was the most commonly used hormonal contraceptive method in all age groups. However, the use of COCs decreased during the period, especially in those below 25 years, where a corresponding increase in the use of LARC has taken place, mainly from 2014 onwards. The inclusion of implants and IUDs in the reimbursement scheme in 2015 , and the authorization of public health nurses and midwives from 2016 to prescribe all hormonal contraceptives including LARCs for women 16 years and older may explain this increase. Especially for women aged 16-19 years, public health nurses and midwives 
prescribed LARCs to more women than doctors from 2017 and onwards. $80 \%$ of all women who started with $\mathrm{COC}$ received the recommended type of $\mathrm{COC}$ from 2016 onwards. Use of estrogen-free contraceptives, i.e. LARCs and gestagen pills, has increased during the study period. The steep increase in use of LARCs after 2014 among younger women was mainly driven by an increased use of subdermal implants. The use of gestagen pills has also increased in younger women over the period, but less and more evenly than the use of LARCs. Oslo had the lowest proportion of users of hormonal contraceptives among teenagers and young adults during the whole period, while among those 3049 years Oslo was more in line with the other counties.

Both the Norwegian and European Medicines Agency have recommended new users of $\mathrm{COC}$ to use the $2^{\text {nd }}$ generation $\mathrm{COC}$ containing levonorgestrel. In addition, they have recommended that more women should be prescribed LARCs to prevent unwanted pregnancies and abortions, especially among younger women. The fact that since 2016 four out of five new users obtained the recommended COCs and the steep increase in use of LARCs in later years implies high compliance with these recommendations in Norway. Public health nurses and midwives contribute to a great extent to this increase. Ekman and Skjeldestad have shown that public health nurses and midwives had the highest compliance with the prescribing recommendations (12). In their annual report of adverse events in 2017, NoMA stated they had not received any reports of deaths due to pulmonary embolism in users of COCs for the past seven years. They also reported a marked decrease in the number of admissions for deep vein thrombosis among young women in general in the period 2011-2016 according to data from the Norwegian Patient Register (13).

LARCs provide an increased protection against unwanted pregnancies since implants and intrauterine devices have few or no user errors. In recent years, LARCs have increasingly been recommended in most countries as a strategy to reduce unintended pregnancies and abortion rates (14-17). We demonstrate an increase in dispensing of LARCs from 2015 especially among the younger women. The decline in abortions in Norway has been highest among women younger than 25 years where there has been the largest increase in the use of LARCs (18). The age group 20-24 years has long had the highest incidence of abortions but has since 2016 been lower than the abortion rate in the age groups 25-29 years and 30-34 years. An important contribution to the increase in use of LARCs may be both the extensions of providing all types of hormonal contraception free of charge to younger women from 1 January 2015 and giving the public health nurses right to also prescribe LARCs from 2016. This increase is in accordance with the recommendations from the health authorities. Smaller IUDs were introduced to the Norwegian market in 2014 and 2017 (Jaydess ${ }^{\circledR}$ and Kyleena ${ }^{\circledR}$ ) and these are more acceptable for women who haven't given birth to a child. This may also have contributed to the increased use of IUDs among younger women. In an ecological study Hognert et al found that the increase of LARC use consisted mainly of a higher use of IUD rather than implant in Sweden and Denmark (19).

A recently published article reports two women in Norway with ulnar nerve injuries after removal of subdermal contraceptive implants (20). The implant is placed in the medial upper arm and may lie close to important neuromuscular structures. In both cases, nerve injury occurred during removal of the implant. The authors of the case report recommend that any patient with an implant that is not readily palpable in the subcutaneous tissue should be referred to a hand surgeon who has training in exploring peripheral nerves.

The need for contraception may vary between women with different cultural backgrounds, and a study in Norway by Omland et al found lower use of hormonal contraceptives among immigrants than among women born in Norway without immigrant background. The differences were greatest between the youngest women (21). Oslo has the highest proportion of people with immigrant background in the age-group 16-19 years (38\% in 2020), Viken the second highest (18\%) and Nordland county the lowest proportion $(9 \%)$ of people with immigrant background (22). These differences may partly explain why Oslo has the lowest proportion of users of hormonal contraceptives among teenagers and young adults.

\section{Strengths and limitations}

The NorPD is a well-recognised high-quality data source for examining medication utilisation patterns. However, NorPD lacks information on use of non-hormonal forms of contraception as copper IUDs and condoms. Further, LARCs supplied directly from health clinics, doctors' own practices or by hospitals may not be captured within NorPD. This may lead to an underestimation of total LARC use in our study. However, in 2017, 7000 prescriptions of hormonal contraceptives were provided from pharmacies directly to doctors' own practices or health clinics, and are registered as aggregated data (not linked to the individual woman that received the contraceptives) in the Norwegian Prescription Database (23). These 7000 prescriptions only accounted for $0.06 \%$ of all dispensed contraceptives in 2017 (24). Another limitation is that we have not excluded pregnant women in our analyses, which may also lead to an underestimation of hormonal contraceptive use among women in Norway.

It is reasonable to assume that the NorPD reflects real use of medications. However, filled prescriptions do not necessarily mean that the contraceptives have been used, and no data on discontinuation were available. LARCs tend to give some intolerable side effects, most importantly bleeding disorders, albeit transient, and these are frequently reasons for discontinuation. Nevertheless, when assessing contraceptive use, dispensed contraceptives from pharmacy have been shown to be more reliable than self-reported use, as women tend to overestimate their contraceptive use (25). 
In summary, our results show a marked increase in the use of the preferred hormonal contraceptives (LARC, gestagen pill, COC with levonorgestrel) that reduce the risk of VTE. The prescribing doctors, public health nurses and midwives in Norway have high compliance with the recommendations from the health authorities.

\section{Funding}

The study was partly supported by NordForsk Nordic Program on Health and Welfare (Nordic Pregnancy Drug Safety Studies, project No. 83539), by the Research Council of Norway (International Pregnancy Drug Safety Studies, project No. 273366) and by the Research Council of Norway through its Centres of Excellence funding scheme (project No. 262700).

\section{REFERENCES}

1. van Hylckama Vlieg A, Helmerhorst FM, Vandenbroucke JP, Doggen CJ, Rosendaal FR. The venous thrombotic risk of oral contraceptives, effects of oestrogen dose and progestogen type: results of the MEGA case-control study. BMJ 2009;339:b2921.

2. Lidegaard O, Lokkegaard E, Svendsen AL, Agger C. Hormonal contraception and risk of venous thromboembolism: national follow-up study. BMJ 2009;339:b2890.

3. Harg P, Hortemo S. The risk of thromboembolism of hormonal contraceptives - updated knowledge [Ny kunnskap om blodproppfaren ved hormonelle prevensjonsmidler]. In Norwegian, English summary. Norsk Farmaceutisk Tidsskrift 2015;4:18-21.

4. Benefits of combined hormonal contraceptives $(\mathrm{CHCs})$ continue to outweigh risks. Product information updated to help women make informed decisions about their choice of contraception. https:/www.ema.europa.eu/en/ medicines/human/referrals/combined-hormonal-contraceptives. European Medicines Agency, 2014.

5. Informasjon til helsepersonell (Brev). Kombinerte hormonelle prevensjonsmidler: Vær oppmerksom på forskjeller mellom preparatene når det gjelder risiko for blodpropp og betydningen av individuelle risikofaktorer. 14. januar 2014. Summary of EMA's review of risks and benefits of combined hormonal contraceptives, 2014.

6. Rundskriv - Retningslinjer for helsesøstres og jordmødres rett til å rekvirere prevensjonsmidler til unge kvinner i alderen 16 til og med 19 år. Helsedepartementet, 2002. https://www.regjeringen.no/globalassets/upload/kilde/hd/rus/2002/0011/ddd/pdfv/158164-innmat.pdf.

7. Forebygging av uønsket svangerskap og abort blant tenåringer. Innføring av fast bidragssats for dekning av utgifter til hormonell prevensjon til unge kvinner i alderen 16 til og med 19 år. Rundskriv I-1/2006 fra HOD. https://www.regjeringen.no/globalassets/upload/kilde/hod/rus/2006/0004/ddd/pdfv/274267-rundskriv.pdf.

8. Stønad til prevensjon for unge kvinner. https:/www.helfo.no/regelverk-og-takster/stonad-til-prevensjon-forunge-kvinner/stonad-til-prevensjon-for-unge-kvinner. HELFO, 2019.

9. Johansen M. eMetodebok for seksuell helse. Prevensjonsmidler. https://emetodebok.no/kapittel/prevensjonsmidler/ Sex og Samfunn, Oslo, Norway, 2021.

10. Furu K, Wettermark B, Andersen M, Martikainen JE, Almarsdottir AB, Sorensen HT. The Nordic countries as a cohort for pharmacoepidemiological research. Basic Clin Pharmacol Toxicol 2010;106(2):86-94.

11. WHO Collaborating Centre for Drug Statistics Methodology, Guidelines for ATC classification and DDD assignment 2018. Oslo, Norway, 2017.

12. Ekman J, Skjeldestad FE. Do Norwegian providers comply with national recommendations when prescribing combined oral contraceptives to starters? A cohort study. BMJ Open 2019;9(11):e027888.

13. Statens Legemiddelverk (Norwegian Medicines Agency), 2018. Bivirkningsrapport for 2017 - Hva kan vi lære? Hormonell prevensjon. https://legemiddelverket.no/nyheter/bivirkningsrapport-for-2017-hva-kan-vi-lere.

14. Mazza D, Bateson D, Frearson M, Goldstone P, Kovacs G, Baber R. Current barriers and potential strategies to increase the use of long-acting reversible contraception (LARC) to reduce the rate of unintended pregnancies in Australia: An expert roundtable discussion. Aust N Z J Obstet Gynaecol 2017;57(2):206-12.

15. NICE. Long-acting reversible contraception. Clinical guideline [CG30] Published date: 26 October 2005, Last updated: 02 July 2019. https://www.nice.org.uk/guidance/cg302019.

16. Helsedirektoratet, 2015. Utvidet rekvireringsrett til helsesøstre og jordmødre for prevensjonsmidler Helsesøstre og jordmødres administrering av Langtidsvirkende, reversibel prevensjon (LARC). Rundskriv IS13/2015. https:/www.helsedirektoratet.no/rundskriv/utvidet-rekvireringsrett-til-helsesostre-og-jordmodre-forprevensjonsmidler/.

17. Trussell J. Effect of providing contraception free of charge. Am J Public Health 2018;108(4):435-6.

18. Løkeland M, Heiberg-Andersen R, Akerkar R, Jonasson Ø, Askeland O, Hornæs M, et al. Rapport om svangerskapsavbrot i Norge 2020. [Report on termination of pregnancies in Norway for 2020] Rapport nr. 1-2021. https://www.fhi.no/globalassets/dokumenterfiler/rapporter/2021/rapport-om-svangerskapsavbrot-2020rapport-2021.pdf. Folkehelseinstituttet, 2021.

19. Hognert H, Skjeldestad FE, Gemzell-Danielsson K, Heikinheimo O, Milsom I, Lidegaard O, et al. Ecological study on the use of hormonal contraception, abortions and births among teenagers in the Nordic countries. $B M J$ Open 2018;8(10):e022473. 
20. Thorkildsen RT, Thu F, Myrseth LE, Røkkum M. Alvorlige nerveskader ved bruk av p-stav. Kort kasuistikk. Tidsskr Nor Laegeforen 2021;141.

21. Omland G, Ruths S, Diaz E. Use of hormonal contraceptives among immigrant and native women in Norway: data from the Norwegian Prescription Database. BJOG 2014;121(10):1221-8.

22. Statistikkbanken: Innvandrere og norskfødte med innvandrerforeldre. 07459: Alders- og kjønnsfordeling i kommuner, fylker og hele landets befolkning (K) 1986-2021.

www.ssb.no/statbank/table/07111 and www.ssb.no/statbank/table/074592021.

23. Sommerschild H. (Ed.). Legemiddelforbruket i Norge 2015-2019 - Data fra Grossistbasert legemiddelstatistikk og Reseptregisteret / Drug Consumption in Norway 2015-2019 - Data from Norwegian Drug Wholesales Statistics and the Norwegian Prescription Database. Legemiddelstatistikk/Drug statistics. Oslo, Norway: Norwegian Institute of Public Health, 2020.

24. Aares EB. Bruken av hormonelle prevensjonsmidler, 2004-2017. https://www.duo.uio.no/bitstream/handle/10852/63532/masterdokument_ny.pdf?sequence=1\&isAllowed=y: Master thesisin pharmacy, University of Oslo, Norway, 2018.

25. Triebwasser JE, Higgins S, Secura GM, Zhao Q, Peipert JF. Pharmacy claims data versus patient self-report to measure contraceptive method continuation. Contraception 2015;92(1):26-30. 